\title{
A Glance at Neurofitness in Nutrition Perspective
}

\author{
Saleha Sarfraz ${ }^{1}$, Fatima Hussain Bukhari ${ }^{2}$, Sidra Khalid ${ }^{3 *}$, Maria Aslam ${ }^{4}$, Tabeen $\operatorname{Irfan}^{5}$, Kinza Seher ${ }^{5}$, Raheela Zubair ${ }^{2}$ \\ ${ }^{1}$ University College of Medicine and Dentistry, the University of Lahore Pakistan \\ ${ }^{2}$ Doctor of Dietetics and Nutrition Sciences, University Institute of Diet and Nutritional Sciences, Faculty of Allied Health Sciences, \\ the University of Lahore Pakistan \\ ${ }^{3}$ Senior Lecturer at, University Institute of Diet and Nutritional Sciences, Faculty of Allied Health Sciences, the University of Lahore \\ Pakistan \\ ${ }^{4}$ Assistant Professor at, University Institute of Diet and Nutritional Sciences, Faculty of Allied Health Sciences, the University of \\ Lahore Pakistan \\ ${ }^{5}$ Student of Master of Philosophy in Human Nutrition and Dietetics Lahore Pakistan
}

\section{Article History \\ Received: 26.08.2020 \\ Accepted: 18.09 .2020 \\ Published: 14.10 .2020}

Journal homepage: https://www.easpublisher.com/easjnfs

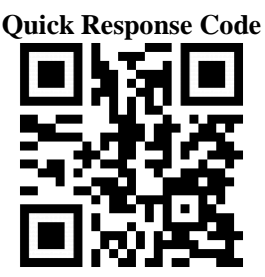

Abstract: Human body composed of four components mind, heart, soul, body these all effect on each other in different way, which may be the cause of disease or heal if we heal ourselves right best thing $\mathrm{s}$ come out of us with world changing power. Microbiota the whole colony of the microorganisms is preset in our body and performing different function affecting our mood decision making abilities. A universe living inside us and with their whole perfections $98 \%$ of our body contains these microorganisms, and only $2 \%$ of our own genome present inside us which tell us how they are controlling us and if through poor food choices how we can affect their growth and they may become cause of several inflammatory diseases. Isalm is the absolute religion which teach us not only Spirituality but also give us the right idea of life how to live and what is being required by a human. Because Allah SWT makes mankind, HE knows what is beneficial for him through food or in any other purposes. Because maker know what and how did he make a thing and what is going be its fuel. Our food our thoughts are fuel of our life if we use rightly we will manage all the relations we have with other humans and surroundings. Nutrients deficiencies such as vitamin B12, B9, B1, B3, A, D, E and omega 3 fatty acids influence the neurological issues. Diet plays a pivotal role in the management of neurological disorders.

Keywords: Neurofitness, Microbiota, Omega-3 fatty acid. Nutrients.

Copyright (C) 2020 The Author(s): This is an open-access article distributed under the terms of the Creative Commons Attribution 4.0 International License (CC BY-NC 4.0) which permits unrestricted use, distribution, and reproduction in any medium for non-commercial use provided the original author and source are credited.

\section{INTRODUCTION}

From old stories to modern medical science tell us about brain and food connection. Food are the chemical signals received by the body and it can directly or indirectly effect our mood, learning abilities, thinking capacity, making decisions, in different disease condition what responses shown by our body and how to be a healing and energy factor in this regard. In other words we can say it is a fuel for the brain to perform a fine function in daily routine life tasks with efficiency [1]. In the studies are being performed in the past and in present regarding its effect on human health and how human health can be reach at its healthiest level. In Linyi peoples hospital china perform a researcher in food and depression relation which tell us how several food consumption and increase and decrease or contribute to depression. For example greater use of salty sugar high fats products or refined factory made highly processed food may contribute to depression or other associated health problems [2]. A study conducted by mood and food centre Deakin university in Australia. Which suggested lower intake of nutrients dense food and high intake of unhealthy food could be the cause of smaller left hippocampal volume [3]. This has been seen unhealthy dietary approaches can be associated with ADHA in children. Although fruits and vegetables rich diet a low risk diet in several mental health disorders and key to the neurofitness[4, 5]. These types of studies help us to understand the nutrition psychology. How multi nutrients play important role in state of mind and other co morbidities [6]. Omega 3 is the most known nutrient in the field of neurology and psychology this has been seen those kids who received omega 3 supplements were less hyperactive and more stable or emotionally controlled [1].

World Health Organization (WHO), defines mental health is "A state of well-being in which the individual realizes his or her own abilities, can cope with the normal stresses of life, can work productively and fruitfully, and is able to make a contribution to his or her community[7]". According to World Health Organization (WHO). Some of the disorders like anxiety, depression, bipolar disorder, autism, eating disorders, panic attacks and hyperactivity may cost 
triple amount in 2030 of current cost in treatments of these disorders [8]. Many reseachers in the past tell us about bidirectional relationship between gut and brain, vagus nerve or microbial neurometabolite production. Imbalance in gut microbial funtions leads to many behavioural and psychiatric problems. But the dietary interventions are being seen as a beneficial in this regard. It may helpful in preventing many neurological diseases, and improve brain functioning and fitness [9].
This has been seen those who lack the important phase of development during their childhood are being more facing difficulties regarding learning, habits, memory, etc [10]. Pakistan has reported the world leading rank countries, according to National Nutrition survey, $33 \%$ underweight, $44 \%$ sunted, $15 \%$ wasted, $50 \%$ or nearly were anemic. These statistics roughly can tell us about the learning abilities of the children Pakistan and their neurofitness[11].

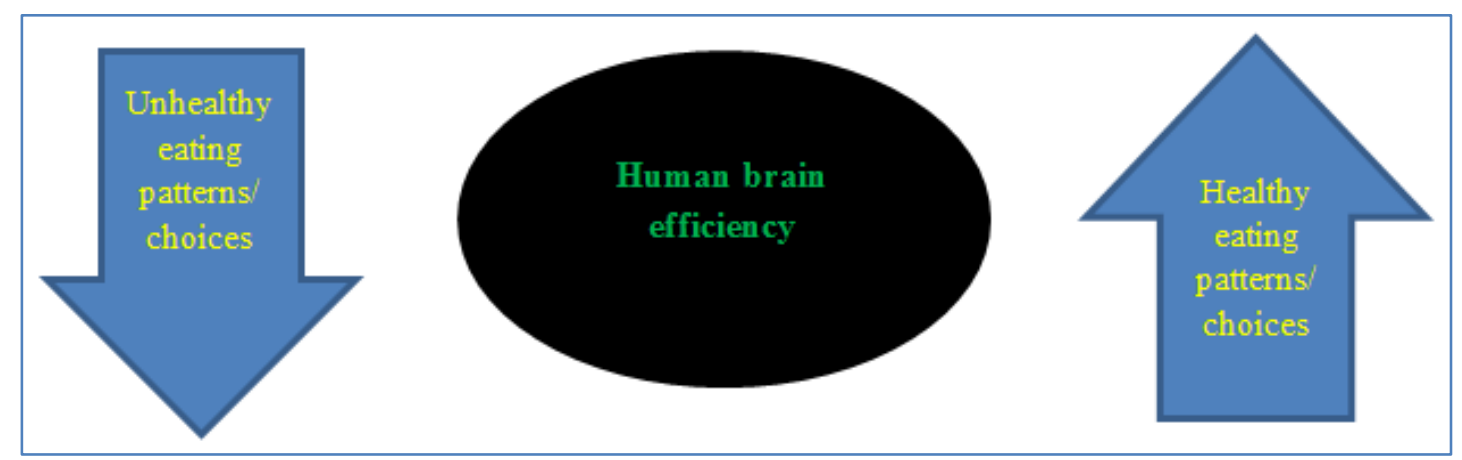

Fig-1: Relationship of food with brain efficiency

\section{Brain - gut axis}

A large number of microbes live in our gut specially in small and large intestine, this has been said that bacterial cells are more in ratio of human cell 10 to 1 , and they are involved in encoding of our genes more than human genes[12]. With the help of genomic technologies it becomes possible to see which type and how much microbial content are present and where, bacteria, virus, fungi, protozao, archea, 75\% beacterial load is present in a adult gut [13]. Microbiota plays a very important role in the development of human immune system, metabolizing of nutrients, drugs, and in the production of vitamins and bioactive compounds [14]. We can say now 50\% modification in microbiota is due the change in our food choices, it can bring the change to it in just few days $[15,16]$. The fluctuation in the gut microbiota due to food or any surrounding causes can leads to dsybiosis, overproduction of microorganisms at the end (pathobionts)[17]. This sort of change mostly leads to damage of intestinal lumen which produces leaky gut, and further become a cause of chronic inflammatory diseases and alternation in the central nervous system working capacity $[18,19]$. It can contribute to behavrioural and coginative abnormalities as gut microbiata influence the CNS functioning [20]. Gut microbiota can tell which nutrient to bioactive signaling compunds can be taken out from the food of the host [21]. Molecules like serotonin, gammaaminobutyric acid( GABA) these are neuro active molecules they can modulate the eneteric nervous system through the neuro signaling and can influence behavior and brain function of the host [22]. This two way pathway plays an important role in balancing between neural, hormonal, immunological responses, such as producing cytokines by mucosal immune cells [23]. Nutrients present in the lumen of GI tract and the ecosystem of microbes in the GI tract influences the entero-endrocrine cells responses which designated as the largest endocrine organ in the human body [24].

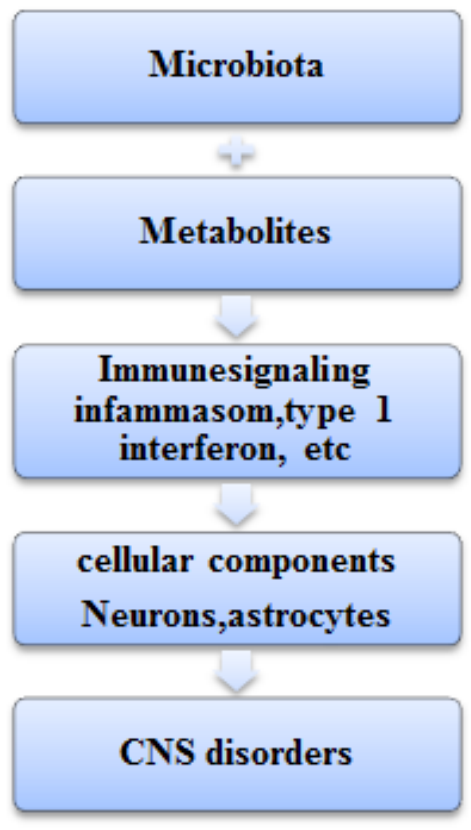

Fig-2: Microbiota Interaction to cause CNS

Figure 2 explains the process of how microbiota interacts with the metabolites to cause CNS disorders [25]. These EESs are very important in different processes of GI tract they can bring the in ion transport which are the source of appetite, insulin secretion and motility etc[26]. Nerves and the hormonal signaling between the gut, the sensory responses of the gut may involve in many influencing factors like food and microbiota modulate the sensory receptors that may release hormons in responses, and brig about the number of functional changes in alimentary canal, high 
fat diet may increase the uptake of energy as it may bring the many changes in GI tract [27]. About 200 to 600 million neurons are present in enteric nervous system which relates to gut. Vagus nerve a parasympathetic nerve a division of the autonomic nervous system has a important role in the bidireational pathway of GI tract and CNS [26, 28] The gut of human act as a endocrine organ as well produce microbial and neurometabolites, like short chain fatty acids nerurotransmitters like serotonin and GABA which may influence the human behavior, vitamins which bring out the brain and gut connecetion[29, 30]. Short chain fatty acids like butyrate and propionate involve infuntioning of brain in terms of appetite and hemostasis by regulating the neuropepetide production [31]. These short chain fatty acids are being produce by the bacteria present in the gut Roseburia spp and Faecalibacterium by the fermentation process of polysaccrides[32].

The inner lining of the gut( epithelial) controlled by Gut microbiota which may not enter the endotoxin into the bloodstream. Increased permeability leads to large amount of lipopolysaccharides in the blood which may cause inflammation. Diet and obesity increase the chance of inflammation prebiotics supplementation play a fine role in effecting inflammation [30]. This chronic inflammation directly or indirectly linked with neurological disorders like dementia, depression, etc. different researches are being conducting to see the benefits of probiotics in psychiatric issues or neurofitness issues [34]. This has been seen gut microbiota is linked with neuro-psyche health in different ways [20] and the part of nutrition in aetiology of brain related disorders and their link with it, there has been seen a benefits of psychobiotics in human to perform different function of brain or may influence [35]. Lactobacillus casei and bifidobacterium longum, bifidobacteria has been seen as a anxiety depressor in humans [36].

\section{Prophetic teaching and its effect on human brain health}

The life style of Muhammad (s.a.w) is the best example for human in each and every walk of life, that could be psychological, physical, spiritual, guide us properly how to live life, as holy Quran said about prophet Muhammad (s.a.w) "you are of a great moral character" (Al Najm 68:4\}[37]. He is the most compassionate, and we have not sent you, [O Muhammad], except as a mercy to the worlds (Al Anbeya"e21:107) [38]. "The son of Adam does not fill any vessel worse than his stomach. It is sufficient for the son of Adam to eat a few mouthfuls, to keep him going. If he must do that (fill his stomach), then let him fill one third with food, one third with drink and one third with air." Prophet Muhammed PBUH [39]. Now research has proven that our brain get the response of food after 20 minutes of eating if we use this hadis as a hidayat we will not gain weight and donot develop unhealthy eating habits [40]. "A man from among the Companions of the Prophet (PBUH) said, 'The Prophet (PBUH) forbade (mixing) unripe dates and dried dates, and (mixing) raisins and dried dates. Aisha, (may Allah be pleased with her), related that, "The Apostle of Allah (PBUH) used to eat melon with fresh dates, and he used to say, 'The heat of the one is broken by the coolness of the other, and the coolness of the one by the heat of the other [41].'

Now science has proven that dates are very beneficial for brain health it lets not brain inflamed. And watermelon is the fruit which gives feeling of fullness to early and manage the high content of water and work as a antioxidant [42]. This has been seen 800000 people die every year due to committing suicide, mostly are rich people and between the age of 17to 34 according to World health organization data [43] being a Muslim suicide is strictly prohibited that why the ration in the Muslim countries is too much lower the non-Muslims countries [44].

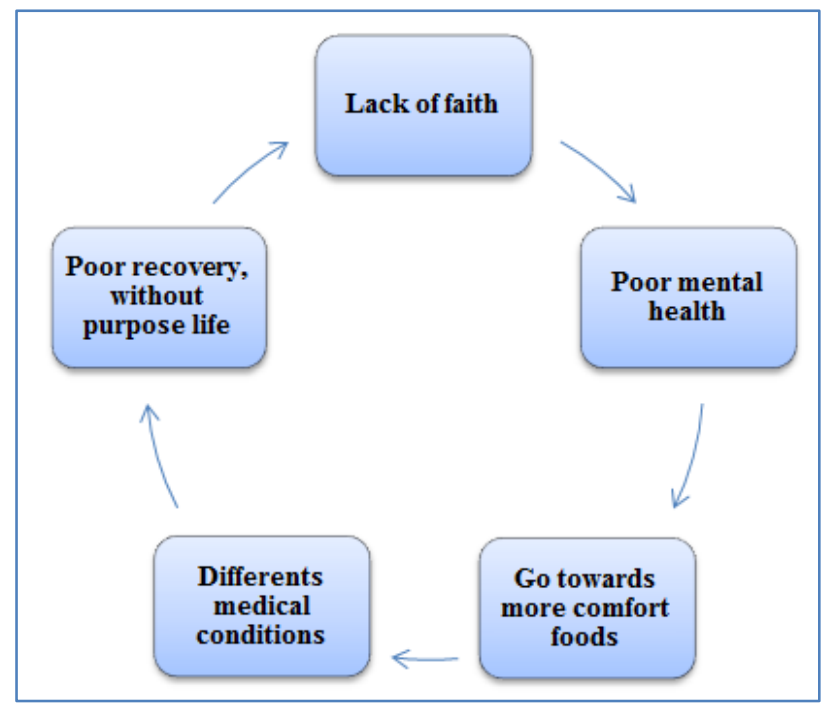

Fig-3: Relationship of faith with mental health 
Poor mental health and lack of faith take us towards bad habits like different addictions of substances which effect eventually our food choices and the cycle keep on repeating [45]. A depress person mostly go towards the comfort food which are high in sugar and fats ultimately leads to poor mental health [46]. Faith give us a purpose, let us know we are different from animals, took us towards self actualization. Spirituality taught by faith in Allah, the knowledge given by Muhammad (s.a.w) how to live life is the best example [47]. Indeed, those who have said, "Our Lord is Allah," and then remained on a right course - there will be no fear concerning them, nor will they grieve (Al Ahkaf 46:13) [48]. Even the listening of holy Quran can be useful for mental health or gives relaxations of mind [49]. Salah play very important role in neurofitness and a positive impact on metabolism of the individual, it depends of the person although this has been seen six minutes of Salah can burn 35 to 80 calories according to individual weight and height [50].

This unique type of body movement found very helpful, can be consider slow moderate exercise having many health benefits like increases muscles flexibility, yoga like activity [51, 52]. The activity during salah is very usefull in nourishinf heart, kidney, impotence of men increase quality of sex and recovery of genital muscle [52]. The Prophetic advices about foods, "'A'isha the wife of Allah's Apostle said: When there was any bereavement in her family the women gathered there for condolence and they departed except the members of the family and some selected persons. She asked to prepare talbina in a small couldron and it was cooked and then tharid was prepared and it was poured over talbina, then she said: Eat it, for I heard Allah's Messenger as saying: Talbina gives comfort to the aggrieved heart and it lessens grief[8, 53]. We can avoid most of the diseases if we eat the natural and seasonal foods, written Chemistry of Man [54]. In Pakistan traditionally faith has used to deal with several mental health issues, mental health mostly come in supernatural influences the perception mostly taken by Pakistani public. $[55,56]$. Spirituality play an important role in holistic and palliative care though could be usefull before treating mental illness [57].

\section{Nutrients helpful for brain}

Numerous food items possess the large amount of the nutrient which are helpful for brain functioning, this has been seen in aging process that low level of cardiovascular fitness, stress, poor diet make a powerful contribution of atrophy of hippocampus and mild cognitive impairtment [58].

\section{Omega-3 fatty acids}

Omega-3 fatty acids play important role in depression and mood disorders as different studies suggested that, alpha-linolenic acid (ALA), eicosapentaenoic acid (EPA), docosahexaenoic acid (DHA) [59]. DHA is the ample omega -3 fatty acid in the brain relatively others [60]. Omega-3fatty acids are involve in help to build cell membrane throughout the body, body itself cannot prepare it, have to consume in diet or supplementation [61]. PUFA involvel in brain functioning through lots of ways like signaling, activations of receptors, endocannabinoid system, DHA, AA involved in neuroinflammation, neurotransmission, gene transcription [62]. Dietary deficiency of omega -3 fatty acids include many psychiatric diseases, like depression, anxiety, bipolar disorder, autism, dementia, schizophrenia, attentiondeficits/hyperactivity disorder [63]. 200-500mg for normal adults has been recommended by many organizatios [66]. RDA for ALA is $1.6 \mathrm{~g}$ /day for men and $1.1 \mathrm{~g} /$ day for women [73].

Table-1: Food items which contain omega-3 fatty acids

\begin{tabular}{|l|l|l|l|}
\hline Food items gram per servings & ALA & DHA & EPA \\
\hline Flax seed oil, 1 tsp & 7.26 & & \\
\hline Chia seeds, 1 ounce & 5.06 & & \\
\hline English walnut ,1 ounce & 2.57 & & \\
\hline Egg cooked 1 egg & & 0.3 & \\
\hline Chicken breast roasted 2 ounce & & 0.02 & 0.01 \\
\hline
\end{tabular}

\section{Honey and black cumin (seed)}

This is the most powerful healer in prophetic medicines, mostly beneficial in all diseases. Its advantage has been discussed in holy Quran many times. 'The bee as a, and your Lord inspired to the bee, "Take for yourself among the mountains, houses, and among the trees and that which they construct. Then eat from all the fruits and follow the ways of your Lord laid down [for you]." There emerges from their bellies a drink, varying in colors, in which there is healing for people. Indeed in that is a sign for a people who give thought'? The Prophet Muhammad (Peace Be Upon Him) said "Honey is a medicine for the body, Quran is medicine to the soul [65]. Honey contains protein calcium, phosphorus, iron, niacin, vitamin $\mathrm{c}$ and other minerals, and sugar. Black seed flavonoids which are consider being the source of good memory and mood and it also contains vitamins $\mathrm{A}, \mathrm{B}, \mathrm{C}$ niacin potassium, iron. Daily treatment with the black seed increased serotonin, 5 hydroxytryptamine [5-TH] and decreased hydroxyl indole acetic acid [5HIAA], in the brain act as anti anxetic[66, 67].

\section{Vitamins and minerals}

Vitamins and mineral deficiencies leads to many central and peripheral nervous system damage 
these deficiencies should not be avoided at any cost mediators etc [68].

because they involve in many reaction as co enzyme,

Table-2: Different nutrients and their role in neurological disorders and how deficiencies play their part. Food are being mentioned which may help to overcome the deficiencies.

\begin{tabular}{|c|c|c|c|c|}
\hline $\begin{array}{l}\text { Vitamins } \\
\text { /minerals }\end{array}$ & Sources & Deficiencies & $\begin{array}{l}\text { Neurological defects } \\
\text { due to deficiencies. }\end{array}$ & $\begin{array}{l}\text { Normal } \\
\text { dosage. }\end{array}$ \\
\hline $\begin{array}{l}\text { B12 } \\
\text { (cobalamine) }\end{array}$ & $\begin{array}{l}\text { Sea food, poultry, dairy } \\
\text { products, supplemented food } \\
\text { whole grains [69]. }\end{array}$ & $\begin{array}{l}\text { Pernicious anemia, } \\
\text { advanced age (due to } \\
\text { atrophic gastritis and } \\
\text { food-cobalamin } \\
\text { malabsorption), gastric } \\
\text { surgery, acid reduction } \\
\text { therapy, gastrointestinal } \\
\text { disease, parasitic } \\
\text { infestation, rarely strict } \\
\text { vegetarianism[71], } \\
\text { often unknown }\end{array}$ & $\begin{array}{lr}\begin{array}{l}\text { Different types } \\
\text { neuropathies }\end{array} & \text { of } \\
\text { Alzheimer } & \text { and } \\
\text { Dementia[70] } & \end{array}$ & $\begin{array}{l}2.4 \mathrm{mcg} \\
{[69]}\end{array}$ \\
\hline B9(folate) & $\begin{array}{l}\text { In mostly in green leafy } \\
\text { vegetables, fresh fruits, nuts, } \\
\text { dairy products, eggs, organ } \\
\text { meat poultry, seafood); found } \\
\text { in bread and cereal group[69], }\end{array}$ & $\begin{array}{l}\text { Alcoholism, } \\
\text { gastrointestinal } \\
\text { disorders, folate } \\
\text { metabolisms problems. }\end{array}$ & $\begin{array}{l}\text { Psychosis, behavior } \\
\text { changes [70] }\end{array}$ & $\begin{array}{l}400 \mathrm{mcg} \\
{[69]}\end{array}$ \\
\hline B1(thiamine) & $\begin{array}{l}\text { fortified, whole-grains/bread } \\
\text { and cereals products, legumes, } \\
\text { dry fruits[69], }\end{array}$ & $\begin{array}{l}\text { Excessive unhealthy } \\
\text { weight loss, chronic } \\
\text { disorders, obesity[72] }\end{array}$ & $\begin{array}{l}\text { Beriberi Wernicke } \\
\text { encephalopathy, } \\
\text { Korsakoff syndrome } \\
{[70]}\end{array}$ & $\begin{array}{l}\text { 50-100mg } \\
\text { /IV }\end{array}$ \\
\hline B3( niacin) & $\begin{array}{l}\text { Sea food, poultry, dairy } \\
\text { products, fortified/whole-grain } \\
\text { cereals, legumes }\end{array}$ & $\begin{array}{l}\text { Absorption related } \\
\text { problems, vitamin B6 } \\
\text { deficiency, patient on } \\
\text { dialysis go through it. }\end{array}$ & $\begin{array}{l}\text { Encephalopathy, alter } \\
\text { gait. Numbness.[70] }\end{array}$ & $\begin{array}{l}\text { 35miligram } \\
\text { /day[69] }\end{array}$ \\
\hline $\begin{array}{l}\text { B6( } \\
\text { pyridoxine })\end{array}$ & $\begin{array}{l}\text { Sea food poultry soybeans, dry } \\
\text { fruits chickpeas, dairy } \\
\text { products, starchy vegetables, } \\
\text { non-citrus fruits, bread and } \\
\text { cereal group }\end{array}$ & $\begin{array}{l}\text { Vitamin B6 absorption } \\
\text { problem, Gut related } \\
\text { disease[70] }\end{array}$ & $\begin{array}{l}\text { Seizures,. Convulsion. } \\
\text { Depression and } \\
\text { irritability [73]. }\end{array}$ & $\begin{array}{l}1.3 \mathrm{mg} / \mathrm{day}[ \\
69]\end{array}$ \\
\hline Vitamin A & $\begin{array}{l}\text { Liver carotene carrots, papaya, } \\
\text { oranges, green leafy } \\
\text { vegetables. }\end{array}$ & $\begin{array}{l}\text { Excessive use of rice } \\
\text { and wheat in diet, } \\
\text { alcoholism, } \\
\text { Malabsorption }\end{array}$ & $\begin{array}{l}\text { Nyctalopia } \\
\text { altered taste buds, } \\
\text { keratinization (cornea, } \\
\text { conjunctiva, respiratory, } \\
\text { gastrointestinal, urinary } \\
\text { tract) autism spectrum } \\
\text { disorder [74] }\end{array}$ & $\begin{array}{l}900 \text { male, } \\
700 \\
\text { female/day } \\
{[69]}\end{array}$ \\
\hline Vitamin E & $\begin{array}{l}\text { Vegetable oil, leafy vegetable, } \\
\text { nuts, meat cereals. }\end{array}$ & $\begin{array}{l}\text { Ataxia with vitamin } \mathrm{E} \\
\text { deficiency, } \\
\text { homozygous } \\
\text { hypobetalipoproteinemi } \\
\text { a, abetalipoproteinemia, } \\
\text { chylomicron retention } \\
\text { disease [75] }\end{array}$ & $\begin{array}{l}\text { Spinocerebellar } \\
\text { syndrome with dorsal } \\
\text { column involvement and } \\
\text { peripheral neuropathy, } \\
\text { ophthalmoplegia, } \\
\text { pigmentary retinopathy }\end{array}$ & $\begin{array}{l}15- \\
19 \mathrm{mg} / \text { day[ } \\
69]\end{array}$ \\
\hline Vitamin D & $\begin{array}{l}\text { Sun is its natural source, } \\
\text { poultry, dairy products organ } \\
\text { meat. }\end{array}$ & $\begin{array}{lll}\text { Poor sun light } \\
\text { exposure, GIT } \\
\text { absorption, }\end{array}$ & $\begin{array}{l}\text { Poor brain functioning } \\
\text { due to inflammation[25] }\end{array}$ & $\begin{array}{l}10- \\
20 \mathrm{mcg} / \mathrm{day}\end{array}$ \\
\hline Copper & $\begin{array}{l}\text { Organ meat, sea food, nuts, } \\
\text { whole grains, legumes }\end{array}$ & $\begin{array}{l}\text { Zinc toxicity, surgery, } \\
\text { dietary deficiency. }\end{array}$ & $\begin{array}{l}\text { Myelopathy } \\
\text { Myeloneuropathy } \\
{[80]}\end{array}$ & $900 \mathrm{mcg}$ \\
\hline Iron & $\begin{array}{l}\text { Organ meat, pulses, fruits, } \\
\text { nuts, }\end{array}$ & $\begin{array}{l}\text { Dietary deficiency, } \\
\text { bleeding } \\
\text { disorders,/carbonated } \\
\text { drinks [69]. }\end{array}$ & $\begin{array}{l}\text { Confusion, fall. } \\
\text { Impaired brain } \\
\text { functioning }[81,82]\end{array}$ & $\begin{array}{l}8 \mathrm{mg} \\
\text { male/18mg } \\
\text { female } \\
{[69] .}\end{array}$ \\
\hline
\end{tabular}




\section{CONCLUSION}

The food we consume effect our brain in different way, if we use more knowledgably we can get best out of our food, extra use of junk food may leads to many diseases and leaves very bad impact on our brain. If we develop habit of these food it may consider dangerous for brain functioning. What we eat we become. Human comprises on 4 things and these four things need to be recovered or nourished properly so we will be able to get to achieve the reality of life. We have to nourish our soul, our mind, our heart; lastly our body and these all are interlinked, which make us a successful in every walk of life.

\section{Conflicts of interest}

The author declares that there is no conflict of interest to declare.

\section{REFERENCES}

1. Selhub, E. (2015). Nutritional psychiatry: Your brain on food: Harvard Health Publishing, Harvard Medical School.

2. Li, Y., Lv, M.-R., Wei, Y.-J., Sun, L., Zhang, J.-X., Zhang, H.-G., \& Li, B. (2017). Dietary patterns and depression risk: a meta-analysis. Psychiatry research, 253, 373-382.

3. Jacka, F. N., Cherbuin, N., Anstey, K. J., Sachdev, P., \& Butterworth, P. (2015). Western diet is associated with a smaller hippocampus: a longitudinal investigation. BMC medicine, 13(1), 215.

4. Cortese, S., Moreira-Maia, C. R., St. Fleur, D., Morcillo-Peñalver, C., Rohde, L. A., \& Faraone, S. V. (2016). Association between ADHD and obesity: a systematic review and meta-analysis. American Journal of Psychiatry, 173(1), 34-43.

5. Ríos-Hernández, A., Alda, J. A., Farran-Codina, A., Ferreira-García, E., \& Izquierdo-Pulido, M. (2017). The Mediterranean diet and ADHD in children and adolescents. Pediatrics, 139(2), e20162027.

6. Jacka, F. N., O’Neil, A., Opie, R., Itsiopoulos, C., Cotton, S., Mohebbi, M., . . . Chatterton, M. L. (2017). A randomised controlled trial of dietary improvement for adults with major depression (the 'SMILES'trial). BMC medicine, 15(1), 23.

7. Galderisi, S., Heinz, A., Kastrup, M., Beezhold, J., $\&$ Sartorius, N. (2015). Toward a new definition of mental health. World Psychiatry, 14(2), 231-233.

8. Farshoukh, M. (2019). PROPEHETIC MENTAL HEALTH. AL-'ABQARI: Journal of Islamic Social Sciences and Humanities, 17, 75-96.

9. Oriach, C. S., Robertson, R. C., Stanton, C., Cryan, J. F., \& Dinan, T. G. (2016). Food for thought: The role of nutrition in the microbiota-gut-brain axis. Clinical Nutrition Experimental, 6, 25-38.

10. Yashna, O., Makarenko, O., \& Shapovalova, A. (2018). Neurofitness as a method of psychotherapy for children with psychoneurological pathologies. MHGC Proceedings(2018), 106-107.
11. Asim, M., \& Nawaz, Y. (2018). Child malnutrition in Pakistan: evidence from literature. Children, 5(5), 60.

12. Qin, J., Li, R., Raes, J., Arumugam, M., Burgdorf, K. S., Manichanh, C., . . . Yamada, T. (2010). A human gut microbial gene catalogue established by metagenomic sequencing. nature, 464(7285), 59-65.

13. Collado, M. C., Cernada, M., Baüerl, C., Vento, M., \& Pérez-Martínez, G. (2012). Microbial ecology and host-microbiota interactions during early life stages. Gut microbes, 3(4), 352-365.

14. Lankelma, J. M., Nieuwdorp, M., de Vos, W. M., \& Wiersinga, W. J. (2015). The gut microbiota in internal medicine: implications for health and disease. The Netherlands journal of medicine, 73(2), 61-68.

15. David, L. A., Maurice, C. F., Carmody, R. N., Gootenberg, D. B., Button, J. E., Wolfe, B. E., . . . Fischbach, M. A. (2014). Diet rapidly and reproducibly alters the human gut microbiome. nature, 505(7484), 559-563.

16. Zhang, C., Zhang, M., Wang, S., Han, R., Cao, Y., Hua, W., . . . Wei, C. (2010). Interactions between gut microbiota, host genetics and diet relevant to development of metabolic syndromes in mice. The ISME journal, 4(2), 232-241.

17. Kamada, N., Chen, G. Y., Inohara, N., \& Núñez, G. (2013). Control of pathogens and pathobionts by the gut microbiota. Nature immunology, 14(7), 685.

18. DuPont, A. W., \& DuPont, H. L. (2011). The intestinal microbiota and chronic disorders of the gut. Nature reviews Gastroenterology \& hepatology, 8(9), 523.

19. Sekirov, I., Russell, S. L., Antunes, L. C. M., \& Finlay, B. B. (2010). Gut microbiota in health and disease. Physiological reviews, 90(3), 859-904.

20. Cryan, J. F., \& Dinan, T. G. (2012). Mind-altering microorganisms: the impact of the gut microbiota on brain and behaviour. Nature reviews neuroscience, 13(10), 701-712.

21. Tan, H., \& O'Toole, P. W. (2015). Impact of diet on the human intestinal microbiota. Current Opinion in Food Science, 2, 71-77.

22. Wall, R., Cryan, J. F., Ross, R. P., Fitzgerald, G. F., Dinan, T. G., \& Stanton, C. (2014). Bacterial neuroactive compounds produced by psychobiotics Microbial endocrinology: The microbiota-gutbrain axis in health and disease (pp. 221-239): Springer.

23. de Jonge, W. J. (2013). The gut's little brain in control of intestinal immunity. ISRN gastroenterology, 2013.

24. Lyte, J. M., \& Lyte, M. (2019). Microbial endocrinology: intersection of microbiology and neurobiology matters to swine health from infection to behavior. animal, 13(11), 2689-2698.

25. Ma, Q., Xing, C., Long, W., Wang, H. Y., Liu, Q., \& Wang, R.-F. (2019). Impact of microbiota on central nervous system and neurological diseases: 
the gut-brain axis. Journal of neuroinflammation, 16(1), 53.

26. Furness, J. B., Rivera, L. R., Cho, H.-J., Bravo, D. M., \& Callaghan, B. (2013). The gut as a sensory organ. Nature reviews Gastroenterology \& hepatology, 10(12), 729.

27. Feinle-Bisset, C. (2016). Upper gastrointestinal sensitivity to meal-related signals in adult humansrelevance to appetite regulation and gut symptoms in health, obesity and functional dyspepsia. Physiology \& behavior, 162, 69-82.

28. Schretter, C. E. (2020). Links between the gut microbiota, metabolism, and host behavior. Gut microbes, 11(2), 245-248.

29. Reigstad, C. S., Salmonson, C. E., Rainey III, J. F., Szurszewski, J. H., Linden, D. R., Sonnenburg, J. L., . . . Kashyap, P. C. (2015). Gut microbes promote colonic serotonin production through an effect of short-chain fatty acids on enterochromaffin cells. The FASEB Journal, 29(4), 1395-1403.

30. Suchodolski, J. S. (2018). Gut Brain Axis and Its Microbiota Regulation in Mammals and Birds. The Veterinary Clinics of North America. Exotic Animal Practice, 21(1), 159.

31. Byrne, C., Chambers, E., Morrison, D., \& Frost, G. (2015). The role of short chain fatty acids in appetite regulation and energy homeostasis. International journal of obesity, 39(9), 1331-1338.

32. Brestoff, J. R., \& Artis, D. (2013). Commensal bacteria at the interface of host metabolism and the immune system. Nature immunology, 14(7), 676684.

33. Bischoff, S. C., Barbara, G., Buurman, W., Ockhuizen, T., Schulzke, J.-D., Serino, M., . . . Wells, J. M. (2014). Intestinal permeability-a new target for disease prevention and therapy. $B M C$ gastroenterology, 14(1), 189.

34. Dinan, T. G., Stanton, C., \& Cryan, J. F. (2013). Psychobiotics: a novel class of psychotropic. Biological psychiatry, 74(10), 720-726.

35. Sarris, J., Logan, A. C., Akbaraly, T. N., Amminger, G. P., Balanzá-Martínez, V., Freeman, M. P., Mizoue, T. (2015). Nutritional medicine as mainstream in psychiatry. The Lancet Psychiatry, 2(3), 271-274.

36. Messaoudi, M., Violle, N., Bisson, J.-F., Desor, D., Javelot, H., \& Rougeot, C. (2011). Beneficial psychological effects of a probiotic formulation (Lactobacillus helveticus R0052 and Bifidobacterium longum R0175) in healthy human volunteers. Gut microbes, 2(4), 256-261.

37. Khan, M. M., \& Al-Hilali, M. T.-u.-D. (2020). The Noble Qur'an. Maulana Maududi, 135.

38. Ali, M. M. (2011). Holy Quran: Ahmadiyya Anjuman Ishaat Islam Lahore USA.

39. Pascariu, C., \& Vandeputte, L. (2020). Sustainability Across Generations: What Can We Learn from the Elderly Generation About Sustainability in UAE? Sustainable Development and Social Responsibility-Volume 2 (pp. 271278): Springer.

40. MacDonald, A. (2010). Why eating slowly may help you feel full faster. Harvard Health Blog.

41. Hossain, M. Z. (2014). What does Islam say about dieting? Journal of religion and health, 53(4), 1003-1012.

42. Souli, A., Sebai, H., Rtibi, K., Chehimi, L., Sakly, M., Amri, M., \& El-Benna, J. (2014). Effects of dates pulp extract and palm sap (Phoenix dactylifera L.) on gastrointestinal transit activity in healthy rats. Journal of medicinal food, 17(7), 782786.

43. Chung, D. T., Ryan, C. J., Hadzi-Pavlovic, D., Singh, S. P., Stanton, C., \& Large, M. M. (2017). Suicide rates after discharge from psychiatric facilities: a systematic review and meta-analysis. JAMA psychiatry, 74(7), 694-702.

44. Shah, A., \& Chandia, M. (2010). The relationship between suicide and Islam: a cross-national study. Journal of Injury and Violence Research, 2(2), 93.

45. Burrows, T., Kay-Lambkin, F., Pursey, K., Skinner, J., \& Dayas, C. (2018). Food addiction and associations with mental health symptoms: A systematic review with meta-analysis. Journal of Human Nutrition and Dietetics, 31(4), 544-572.

46. Tomiyama, A. J., Dallman, M. F., \& Epel, E. S. (2011). Comfort food is comforting to those most stressed: evidence of the chronic stress response network in high stress women. Psychoneuroendocrinology, 36(10), 1513-1519.

47. Khan, M. B., \& Sheikh, N. N. (2012). Human resource development, motivation and Islam. The Journal of Management Development, 31(10), 1021-1034.

48. Jassem, Z. A. (2014). The Noble Quran: A Critical Evaluation of Al-Hilali and Khan's Translation. International Journal of English and Education, 3(2), 237-273.

49. Mahjoob, M., Nejati, J., Hosseini, A., \& Bakhshani, N. M. (2016). The effect of Holy Quran voice on mental health. Journal of religion and health, 55(1), 38-42.

50. Kamran, G. (2018). Physical benefits of (Salah) prayer-Strengthen the faith and fitness. Journal of Novel Physiotherapy and Rehabilitation, 2, 43-53.

51. Thompson, W. R., Gordon, N. F., \& Pescatello, L. S. (2010). ACSM's guidelines for exercise testing and prescription: Lippincott Williams \& Wilkins.

52. İMAMOĞLU, O. (2016). Benefits of prayer as a physical activity. International Journal of Sport Culture and Science, 4(Special Issue 1), 306-318.

53. Muslim, S. (2014). Hadith. Sahih Muslim Book, 4.

54. Goodier, J. (2012). Encyclopedia of islamic herbal medicine. Reference Reviews.

55. Bashir, A. (2018). The state of mental health care in Pakistan. The Lancet Psychiatry, 5(6), 471.

56. Javed, A., Khan, M. N. S., Nasar, A., \& Rasheed, A. (2020). Mental healthcare in Pakistan. Taiwanese Journal of Psychiatry, 34(1), 6. 
57. Shukla, D., \& Shukla, K. (2016). Healthcare Transition and Spiritual Health. Journal of The Association of Physicians of India, 64, 66.

58. Fotuhi, M., Do, D., \& Jack, C. (2012). Modifiable factors that alter the size of the hippocampus with ageing. Nature Reviews Neurology, 8(4), 189.

59. Chandola, H., \& Tanna, I. (2014). Role of omega-3 fatty acids in brain and neurological health with special reference to clinical depression Omega-3 fatty acids in brain and neurological health (pp. 163-179): Elsevier.

60. Dyall, S. C. (2015). Long-chain omega-3 fatty acids and the brain: a review of the independent and shared effects of EPA, DPA and DHA. Frontiers in aging neuroscience, 7, 52.

61. Trebatická, J., Dukát, A., Ďuračková, Z., \& Muchová, J. (2017). Cardiovascular diseases, depression disorders and potential effects of omega-3 fatty acids. Physiological research, 66(3).

62. Bazinet, R. P., \& Layé, S. (2014). Polyunsaturated fatty acids and their metabolites in brain function and disease. Nature reviews neuroscience, 15(12), 771-785.

63. Lange, K. W. (2020). Omega-3 fatty acids and mental health. Global Health Journal.

64. Todd, J. (2010). FAO/WHO Consultation on Dietary Recommendations on Total Fat and Fatty Acids. Food New Zealand, 10(3), 12.

65. Aboul-Enein, B. H. (2016). Health-promoting verses as mentioned in the Holy Quran. Journal of religion and health, 55(3), 821-829.

66. Bhat, A. M. (2014). Medicinal Flora in the Tradition of Prophet Muhammad (PBUH). Asian Journal of Research in Social Sciences and Humanities, 4(5), 113-126.

67. Rayhan, M. A., Yousuf, S. A., Rayhan, J., Khengari, E. M., Nawrin, K., \& Billah, M. M. (2019). Black seed honey-A powerful ingredient of prophetic medicine; its neuropharmacological potential.

68. Kumar, N. (2017). Nutrients and neurology. CONTINUUM: Lifelong Learning in Neurology, 23(3), 822-861.

69. Lewis, S. L. (2013). Oxford Handbook of Nutrition and Dietetics. Journal of Nutrition Education and Behavior, 45(5), 479. e471.

70. Kennedy, D. O. (2016). B vitamins and the brain: mechanisms, dose and efficacy-a review. Nutrients, 8(2), 68.

71. Pawlak, R., Parrott, S. J., Raj, S., Cullum-Dugan, D., \& Lucus, D. (2013). How prevalent is vitamin B12 deficiency among vegetarians? Nutrition reviews, 71(2), 110-117.
72. Kerns, J. C., Arundel, C., \& Chawla, L. S. (2015). Thiamin deficiency in people with obesity. Advances in nutrition, 6(2), 147-153.

73. Dakshinamurti, S., \& Dakshinamurti, K. (2013). Handbook of Vitamins

74. Guo, M., Zhu, J., Yang, T., Lai, X., Lei, Y., Chen, J., \& Li, T. (2019). Vitamin A and vitamin D deficiencies exacerbate symptoms in children with autism spectrum disorders. Nutritional neuroscience, 22(9), 637-647.

75. Lloret, A., Esteve, D., Monllor, P., Cervera-Ferri, A., \& Lloret, A. (2019). The effectiveness of vitamin $\mathrm{E}$ treatment in Alzheimer's disease. International journal of molecular sciences, 20(4), 879.

76. Fotuhi, M., Lubinski, B., Trullinger, M., Hausterman, N., Riloff, T., Hadadi, M., \& Raji, C. (2016). A personalized 12-week" Brain Fitness Program" for improving cognitive function and increasing the volume of hippocampus in elderly with mild cognitive impairement. The journal of prevention of Alzheimer's disease, 3(3), 133-137.

77. İMAMOĞLU, O., \& DİLEK, A. N. (2016). Common Benefits of Prayer and Yoga on Human Organism. International Journal of Sport Culture and Science, 4(Special Issue 2), 639-651.

78. Johannessen, B., Skagestad, I., \& Bergkaasa, A. M. (2011). Food as medicine in psychiatric care: which profession should be responsible for imparting knowledge and use of omega-3 fatty acids in psychiatry. Complementary therapies in clinical practice, $17(2), 107-112$.

79. Lutsenko, S., Washington-Hughes, C., Ralle, M., \& Schmidt, K. (2019). Copper and the brain noradrenergic system. JBIC Journal of Biological Inorganic Chemistry, 24(8), 1179-1188.

80. Markova, V., Holm, C., Pinborg, A. B., Thomsen, L. L., \& Moos, T. (2019). Impairment of the developing human brain in iron deficiency: correlations to findings in experimental animals and prospects for early intervention therapy. Pharmaceuticals, 12(3), 120.

81. Mayne, P. E., \& Burne, T. H. (2019). Vitamin D in synaptic plasticity, cognitive function, and neuropsychiatric illness. Trends in neurosciences, 42(4), 293-306.

82. Wu, Q., \& Shah, N. P. (2017). High $\gamma$-aminobutyric acid production from lactic acid bacteria: emphasis on Lactobacillus brevis as a functional dairy starter. Critical Reviews in Food Science and Nutrition, 57(17), 3661-3672. 